\title{
Gallbladder Cancer Pathologic Distant Metastasis TNM Finding v8
}

National Cancer Institute

\section{Source}

National Cancer Institute. Gallbladder Cancer Pathologic Distant Metastasis TNM Finding v8. NCI Thesaurus. Code C134641.

A pathologic finding about one or more characteristics of gallbladder cancer, following the rules of the TNM AJCC v8 classification system as they pertain to distant metastases. 